\title{
Identifying hydro-meteorological events from precipitation extremes indices and other sources over northern Namibia, Cuvelai Basin
}

\begin{tabular}{|c|c|}
\hline \multicolumn{2}{|c|}{$\begin{array}{l}\text { Authors: } \\
\text { Frans C. Persendt }{ }^{1,2} \\
\text { Christopher Gomez }^{1} \\
\text { Peyman Zawar-Reza }^{1}\end{array}$} \\
\hline \multicolumn{2}{|c|}{$\begin{array}{l}\text { Affiliations: } \\
{ }^{1} \text { Department of Geography, } \\
\text { University of Canterbury, } \\
\text { New Zealand }\end{array}$} \\
\hline \multicolumn{2}{|c|}{$\begin{array}{l}{ }^{2} \text { Department of Geography, } \\
\text { History and Environmental } \\
\text { Studies, University of } \\
\text { Namibia, Namibia }\end{array}$} \\
\hline \multicolumn{2}{|c|}{$\begin{array}{l}\text { Correspondence to: } \\
\text { Frans Persendt }\end{array}$} \\
\hline \multicolumn{2}{|c|}{$\begin{array}{l}\text { Email: } \\
\text { fpersendt@unam.na }\end{array}$} \\
\hline \multicolumn{2}{|c|}{$\begin{array}{l}\text { Postal address: } \\
\text { Private Bag X13301, } \\
\text { Windhoek, Namibia }\end{array}$} \\
\hline \multicolumn{2}{|c|}{$\begin{array}{l}\text { Dates: } \\
\text { Received: } 14 \text { Mar. } 2015 \\
\text { Accepted: } 11 \text { Aug. } 2015 \\
\text { Published: } 30 \text { Oct. } 2015\end{array}$} \\
\hline \multicolumn{2}{|c|}{$\begin{array}{l}\text { How to cite this article: } \\
\text { Persendt, F.C., Gomez, C. } \\
\text { \& Zawar-Reza, P., 2015, } \\
\text { 'Identifying hydro- } \\
\text { meteorological events from } \\
\text { precipitation extremes } \\
\text { indices and other sources } \\
\text { over northern Namibia, } \\
\text { Cuvelai Basin', Jàmbá: Journal } \\
\text { of Disaster Risk Studies 7(1), } \\
\text { Art. \#177, } 18 \text { pages. http:// } \\
\text { dx.doi.org/10.4102/jamba. } \\
\text { v7i1.177 }\end{array}$} \\
\hline \multicolumn{2}{|c|}{$\begin{array}{l}\text { Copyright: } \\
\text { (C) 2015. The Authors. } \\
\text { Licensee: AOSIS } \\
\text { OpenJournals. This work is } \\
\text { licensed under the Creative } \\
\text { Commons Attribution } \\
\text { License. }\end{array}$} \\
\hline \multicolumn{2}{|l|}{ Read online: } \\
\hline 回散回 & $\begin{array}{l}\text { Scan this QR } \\
\text { code with your } \\
\text { smart phone or } \\
\text { mobile device } \\
\text { to read online. }\end{array}$ \\
\hline
\end{tabular}

Worldwide, more than $40 \%$ of all natural hazards and about half of all deaths are the result of flood disasters. In northern Namibia flood disasters have increased dramatically over the past half-century, along with associated economic losses and fatalities. There is a growing concern to identify these extreme precipitation events that result in many hydro-meteorological disasters. This study presents an up to date and broad analysis of the trends of hydrometeorological events using extreme daily precipitation indices, daily precipitation data from the Grootfontein rainfall station (1917-present), regionally averaged climatologies from the gauged gridded Climate Research Unit (CRU) product, archived disasters by global disaster databases, published disaster events in literature as well as events listed by Mendelsohn, Jarvis and Robertson (2013) for the data-sparse Cuvelai river basin (CRB). The listed events that have many missing data gaps were used to reference and validate results obtained from other sources in this study. A suite of ten climate change extreme precipitation indices derived from daily precipitation data (Grootfontein rainfall station), were calculated and analysed. The results in this study highlighted years that had major hydro-meteorological events during periods where no data are available. Furthermore, the results underlined decrease in both the annual precipitation as well as the annual total wet days of precipitation, whilst it found increases in the longest annual dry spell indicating more extreme dry seasons. These findings can help to improve flood risk management policies by providing timely information on historic hydro-meteorological hazard events that are essential for early warning and forecasting.

\section{Introduction}

More than $40 \%$ of all natural hazards and about half of all deaths worldwide are the result of flood disasters (Emergency Disasters Database [EM-DAT] 2015a; Ohl \& Tapsell 2000). In recent decades, floods have caused much damage economically and have also affected millions of people, especially in developing countries (Jonkman 2005; Jonkman, Vrijling \& Vrouwenvelder 2008). Of the disaster-related fatalities 31\% were caused by floods worldwide, between 1900 and 2006, and these fatalities are second only to drought (53\%) (Smith 2013). In Africa, research has shown that between 1950 and 2010, floods caused an increase in fatalities by one order of magnitude (Figure 1; Di Baldassarre et al. 2010; EM-DAT 2015b). But studies have also found no evidence that the magnitude of African floods has increased during the 20th century (Di Baldassaree et al. 2010). Yet, others have projected an expected increase in the risk of floods in tropical Africa (Hirabayashi et al. 2008).

In northern Namibia (Figure 2), flood disasters have increased dramatically over the past years, along with associated economic losses, and fatalities (Figure 3; EM-DAT 2015c; Kundzewicz et al. 2014). Many causes for flooding are possible hence most flood disaster events differ widely depending - for example - on the climate and the geography of the drainage basin, amongst other causes (Hofer \& Messerli 2006; Smith 2013).

There is a low to medium confidence in the historical extreme rainfall trends observed over most of Africa, because of partial lack of data, lack of literature, and inconsistency of reported patterns in the literature (Conway et al. 2009; Seneviratne et al. 2012). Observed changes (from ground-based rainfall stations) have been reported for areas extending from Namibia to Angola: including a reduction in late austral summer precipitation as well as an increasing trend in daily rainfall intensity, which has implications for run-off characteristics (Hoerling et al. 2006; New et al. 2006). Extreme precipitation linked to climate change is one of the most widely accepted causes of flood events (Abbas et al. 2014; Simonovic 2012; Teegavarapu 2012), as a result of this the World Meteorological Organisation/Climate Variability and Predictability (WMO/CLIVAR) 


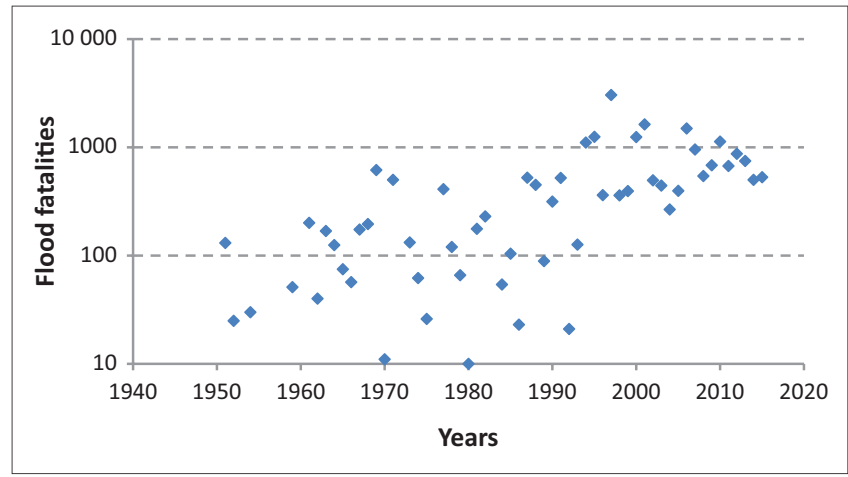

Source: Emergency Disasters Database (EM-DAT), 2015b, Fatalities from meteorological disasters from 1948 to 2015 in Africa, The OFDA/CRED International Disaster Database, Université catholique de Louvain, Brussels, viewed 22 October 2015, from http://www. emdat.be/advanced_search/index.html

FIGURE 1: Statistics of fatalities by flood disaster events from 1950 to 2015 in Africa.

Expert Team on Climate Change Detection, Monitoring and Indices (ETCCDMI 2013) has conducted initial studies on worldwide analysis of both observed temperature and precipitation daily extreme indices. These studies showed noteworthy observed changes in extreme climate indices, for example, they found - during the last 50 years - major increases in heavy rainfall events (Alexander \& Arblaster 2009; Alexander et al. 2006; Frich et al. 2002). Whilst research from southern Africa has shown more variable patterns for all extreme daily precipitation indices except for the maximum 5-day rainfall that presented a consistent pattern of increase, especially during the second half of the twentieth century (Frich et al. 2002).

More research has been undertaken on the observed monthly climate over the southern Africa region resulting from the scarcity and paucity of daily precipitation data. Unganai and Mason (2001) have provided a regional and national overview on recent trends and variability in the monthly climate over Africa. New et al. (2006) have provided the first regional synthesis of trends in daily extremes for southern Africa using extreme precipitation daily indices and they have also provided a very good regional synthesis of extreme precipitation trends over Namibia. In South Africa, many studies on extreme precipitation exist, amongst these Kruger (2006) focused on 138 South African rainfall stations using the indices described in New et al. (2006), whilst Mason et al. (1999), investigated trends in extreme precipitation that had

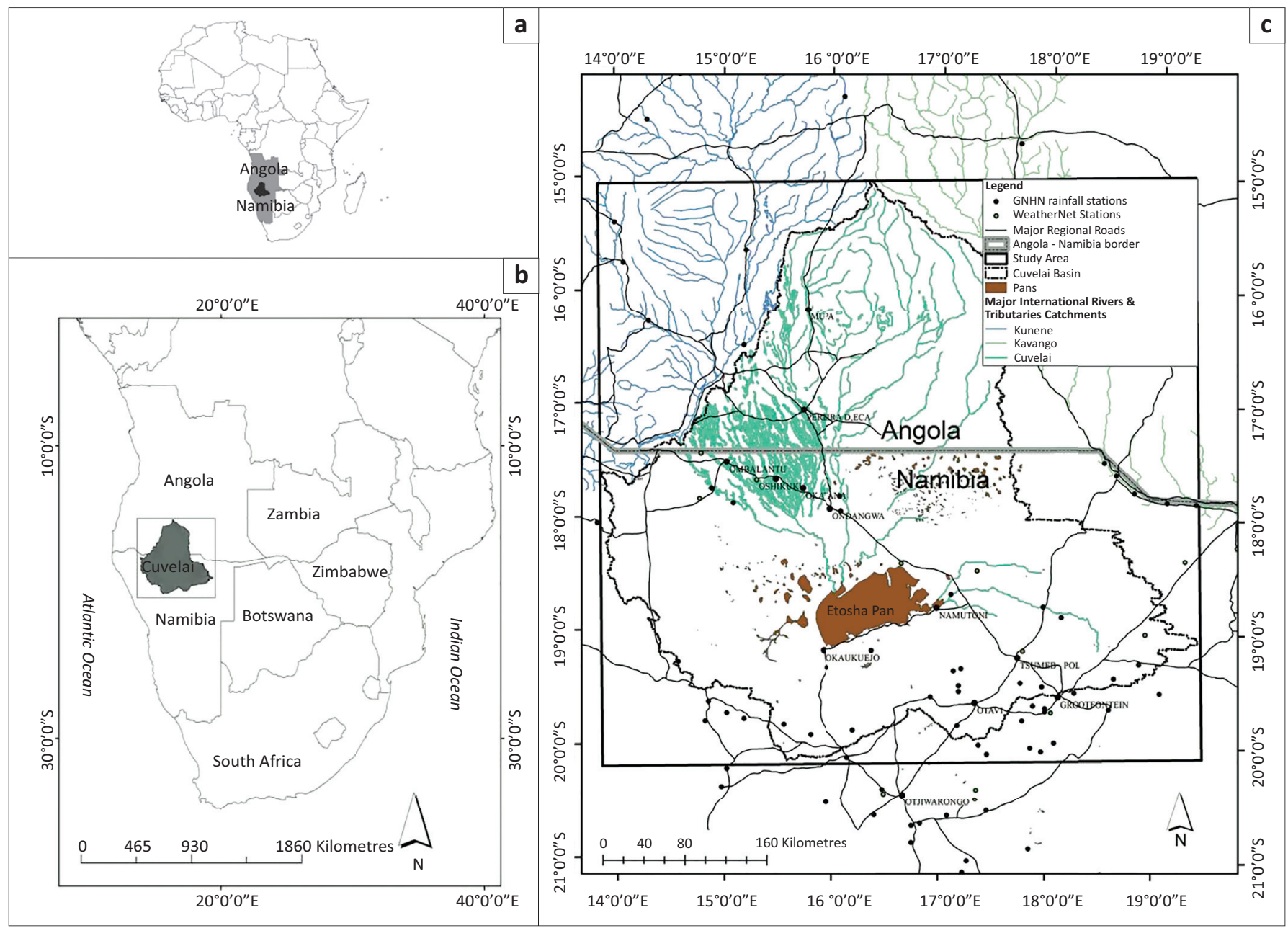

Source: Data on the WeatherNet stations: Helmschrot, J., Muche, G., Hillmann, T., Kanyanga, J., Butale, M., Nascimento, D. et al., 2015, 'SASSCAL WeatherNet to support regional weather monitoring and climate-related research in Southern Africa', paper presented at the Proceedings of the 11th Kovacs Colloquium: Hydrological Sciences and Water Security: Past, Present and Future, IAHS Publications, Paris, June 16-17, 2014, p. 366

FIGURE 2: (a) Location of the Cuvelai River Basin in Africa. (b) The location of the CRB in southern Africa and (c) the CRB with the location of the study area (box) between southern Angola and northern Namibia. The figure also shows all the national rainfall stations as well as the new automatic rainfall stations from the WeatherNet. 


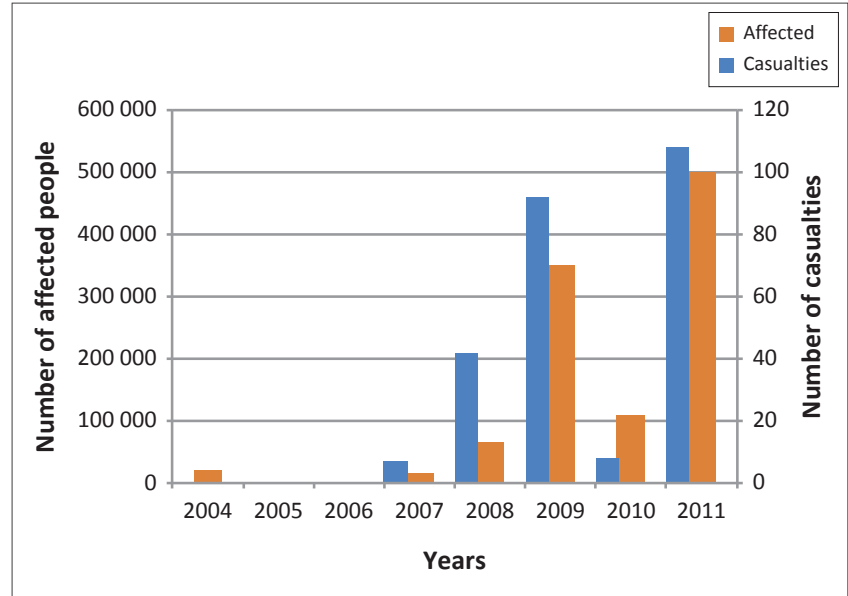

Source: Emergency Disasters Database (EM-DAT), 2015c, Top 10 natural disasters in Namibio for the period 1900 to 2014, The OFDA/CRED International Disaster Database, Universite catholique de Louvain, Brussels, viewed 22 October 2015, from http://www.emdat.be/ country_profile/index.html

FIGURE 3: Inventory data for Namibia from 1900-2014 showing the number of people affected and the casualties caused by flooding.

not experienced locational changes - but without testing for other inhomogeneities. They identified significant increases in the intensity of extreme rainfall events between 1931-1960 and $1961-1990$ over $70 \%$ of South Africa.

Future projections for southern Africa are:

1. medium confidence - that the projected droughts will intensify in the 21st century in some seasons, resulting from reduced precipitation or increased evapotranspiration

2. low confidence - that the projected heavy precipitation will increase. The projected changes for the climatological dry southwest parts of southern Africa have signalled drying in the annual mean as well as during the austral summer months (James \& Washington 2013; Moise \& Hudson 2008; Orlowsky \& Seneviratne 2012).

Furthermore, a projected delay in the onset of seasonal rains in southern Africa is caused by rainfall decreases during austral spring months, and this is also projected for the region (Seth et al. 2011; Shongwe et al. 2009).

In countries qualified as 'developing', such as Namibia, observed climate change time series data and detailed quantitative flood events archives are usually unavailable (Filali-Meknassi, Ouarda \& Wilcox 2014). Qualitative data have been used to derive historical flood events from 1941 to 2013 (Figure 4). Different sources were used to compile this archive (Figure 4) such as flow and flooding extent (levels) as well as fish species types and abundance within the Oshanas (channels) of the CRB (Mendelsohn et al. 2013). The former were derived from hydrography and observational studies that recorded the occurrences of flooding between 1941-1942 and 1960-1961 within the CRB (Stengel 1963) whilst the latter were derived from fish species' type and abundance studies that were used to categorise the magnitude of the flood events between 1975-1976 and 1989-1990 (Van der Waal 1991). Even though this is the most up to date historical record of flood events for the CRB, for the last 73 years, numerous data gaps remain present, for example, no data are available for 13 years. Flood events, in this archive, are qualitatively classified into three classes:

- exceptionally high flows (major flood events) for 11 years: 1949, 1953, 1956, 1970, 1976, 1977, 1995, 2004, 2008, 2009 and 2011

- 18 years of medium flows (medium floods)

- whilst no or only negligible flow (small floods) for 12 years were reported (Figure 4 ).

This archive has also been used to better understand the flooding occurrences in the CRB (Hipondoka 2005; Mendelsohn, el-Obeid \& Roberts 2000; Mendelsohn et al. 2009; Miller, Pickford \& Senut 2010), however, for many years no record of hydro-meteorological disasters have been reported. This study validates and appends possible disaster events for the period 1941-2013, using data from various sources especially for the period from 1960 to 1968 that has no records.

Extreme precipitation events play an important role in monitoring and predicting the occurrence of flood disaster events (Hofer \& Messerli 2006; Wuensch \& Curtis 2010). Furthermore, the evaluation of short and long duration precipitation events is also critical to our understanding of flooding and its impact on natural and built environments (Teegavarapu 2012). Also heavy precipitation (pluvial flooding) in agriculture delays spring planting, increases soil

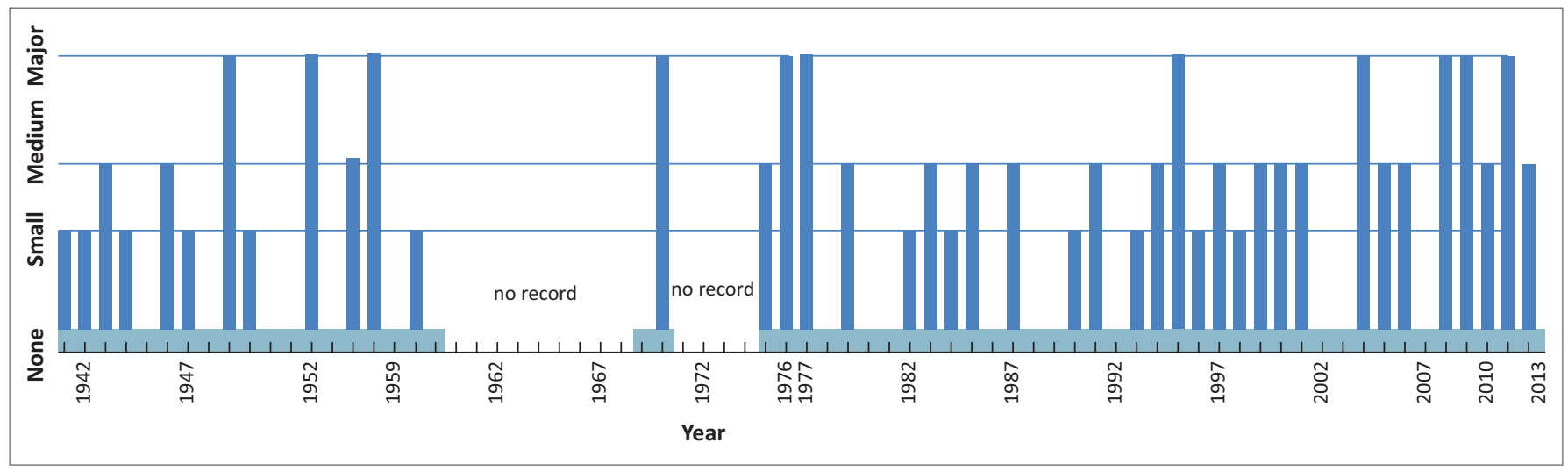

Source: Mendelsohn, J., Jarvis, A. \& Robertson, T., 2013, A profile and atlas of the Cuvelai - Etosha Basin, RAISON \& Gondwana for the Sustainable Integrated Water Resources Management Project, Ministry of Agriculture, Water and Forestry, Windhoek.

FIGURE 4: Flood levels from year-to-year in the CRB, northern Namibia. 
compaction and causes crop losses through anoxia and root diseases, thus, identifying these heavy precipitation events is essential. Additionally, linking rain-induced flooding to certain extreme precipitation events will help with adaptation and improve coping mechanisms. This is especially significant in the low-relief landscape such as the Cuvelai basin that has many pans, which compound the severity of pluvial flooding, as heavy downpours cause these pans to overflow and interlink, causing flooding in the absence of vegetation which buffers run-off (Jury \& Engert 1999).

Hence, the aim of this article is to develop an up to date archive of flood events by comparing referenced flood events listed above to events (years) derived from:

- extreme precipitation indices calculated from data obtained from the Grootfontein rainfall station (longest continuous time series data for northern Namibia)

- regional rainfall stations (New et al. 2006)

- global disasters databases

- rainfall climatologies of the Grootfontein station

- averaged data (area and time - annual) from the CRU TS 3.21 product (Harris et al. 2014; Mitchell \& Jones 2005).

This article contributes towards supplementing geospatial data scarcity that delays the implementation of an efficient and effective flood risk management system in Namibia and also the advancement of climate change adaptation strategies. An updated flood disaster event archive is also essential as flood disaster events are short lived and their spectacular impact is soon forgotten, thus, awareness of the flood disaster event quickly subsides (Barnolas \& Llasat 2007).

\section{Study area}

The CRB is an area of $167600 \mathrm{~km}^{2}$ and is located between $14^{\circ}$ $\mathrm{E}$ and $15^{\circ} \mathrm{E}$ longitude, and $15^{\circ} \mathrm{S}$ and $20^{\circ} \mathrm{S}$ latitude. It extends over $450 \mathrm{~km}$ from north to south and is located between Angola and Namibia. It is surrounded by the Kunene and Okavango rivers to the north-west and north-east respectively (Figure 2). The administrative regions of the basin are comprised of the Omusati, Ohangwena, Oshikoto and Oshana areas in Namibia and the Kunene region in Angola. The basin has a semi-arid climate in the southern part (Namibia) and a subtropical climate in the northern part (Angola), with an annual rainfall ranging from less than $200 \mathrm{~mm}-900 \mathrm{~mm}$ (Figure 5; Mendelsohn \& Weber 2011). The rainfall is highly variable and falls in the austral summer (October - April) mainly resulting from the seasonal north-south movement of the Inter-Tropical Convergence Zone (ITCZ) that brings moist tropical air southwards. During this time, maximum daily temperatures can range between $35{ }^{\circ} \mathrm{C}-40{ }^{\circ} \mathrm{C}$ whilst evaporation and evapotranspiration rates are also at the annual highest.

The dominant vegetation types of the area are the Colophospermum mopane shrubland and woodland (northern part), whilst the saline grasslands are found within different landscapes of the southern part (Kangombe 2010). These landscapes include: the Cuvelai, mopane shrubland,
Karstveld, eastern and west Kalahari woodlands, salt pans and surrounding plains (Mendelsohn \& Weber 2011; Mendelsohn et al. 2009). The study area is densely populated, having the highest population density in Namibia of approximately 100 people per $\mathrm{km}^{2}$, and more than $50 \%$ of the population of Namibia lives in this area (Mendelsohn \& Weber 2011; Mendelsohn et al. 2000; Mendelsohn et al. 2009). It is also host to Namibia's fastest growing rural areas where livelihood strategies for the vast majority of people are from the land (Mendelsohn \& Weber 2011). The land-uses in this region are: rain-fed subsistence farming that is vulnerable to recurring droughts and floods; firewood for energy and building purposes and water for livestock and human consumption. In the southern part, surface water storage facilities are limited resulting from the low topography, high evaporation rates and shallow salty groundwater. The soils in the study area are: sandy, porous and infertile. Hence, these soils have a low probability for use in crop farming but are good for rangeland farming (Mendelsohn et al. 2009), whilst an impermeable layer below the sand compounds the problem (Mendelsohn \& Weber 2011). Furthermore, where this layer occurs, vast areas are inundated with water when it rains for long periods. Additionally, some areas (southern part) have multiple broad channels as well as numerous pans that are composed of waterborne clay which produced fertile soils (cambisols and calcisols) for many agricultural uses (Mendelsohn \& Weber 2011). Lastly, the Mupa National Park (Angola) and the world-renowned Etosha National Park (Namibia) are located within the basin.

\section{Objectives}

A sound and reliable archive on floods and flooding is important to insurance companies, research institutes, and government and financial organisations that can benefit from accurate data. It is also useful for more appropriate and suitable flood management and protection measures, both structural and non-structural, for analysing locational strategies for disaster risk mitigation. Furthermore, it will help institutions optimise their investments to alleviate poverty and to stimulate (economic) prosperity and, finally, many stakeholders are also interested in collecting correct information to improve their knowledge on floods and flooding.

The specific objectives of this article are to:

1. list flood events according to their magnitudes (Table 1 \& Figure 4)

2. document flood events published in literature based on hydro-meteorological data

3. calculate extreme precipitation indices for the Grootfontein station, and compare them to the regional trends (New et al. 2006)

4. calculate climatologies for the Grootfontein rainfall station

5. calculate area averaged climatologies and also anomalies for the CRB using the CRU product data

6. validate the listed flood events (Table 1) against those identified from other sources. 


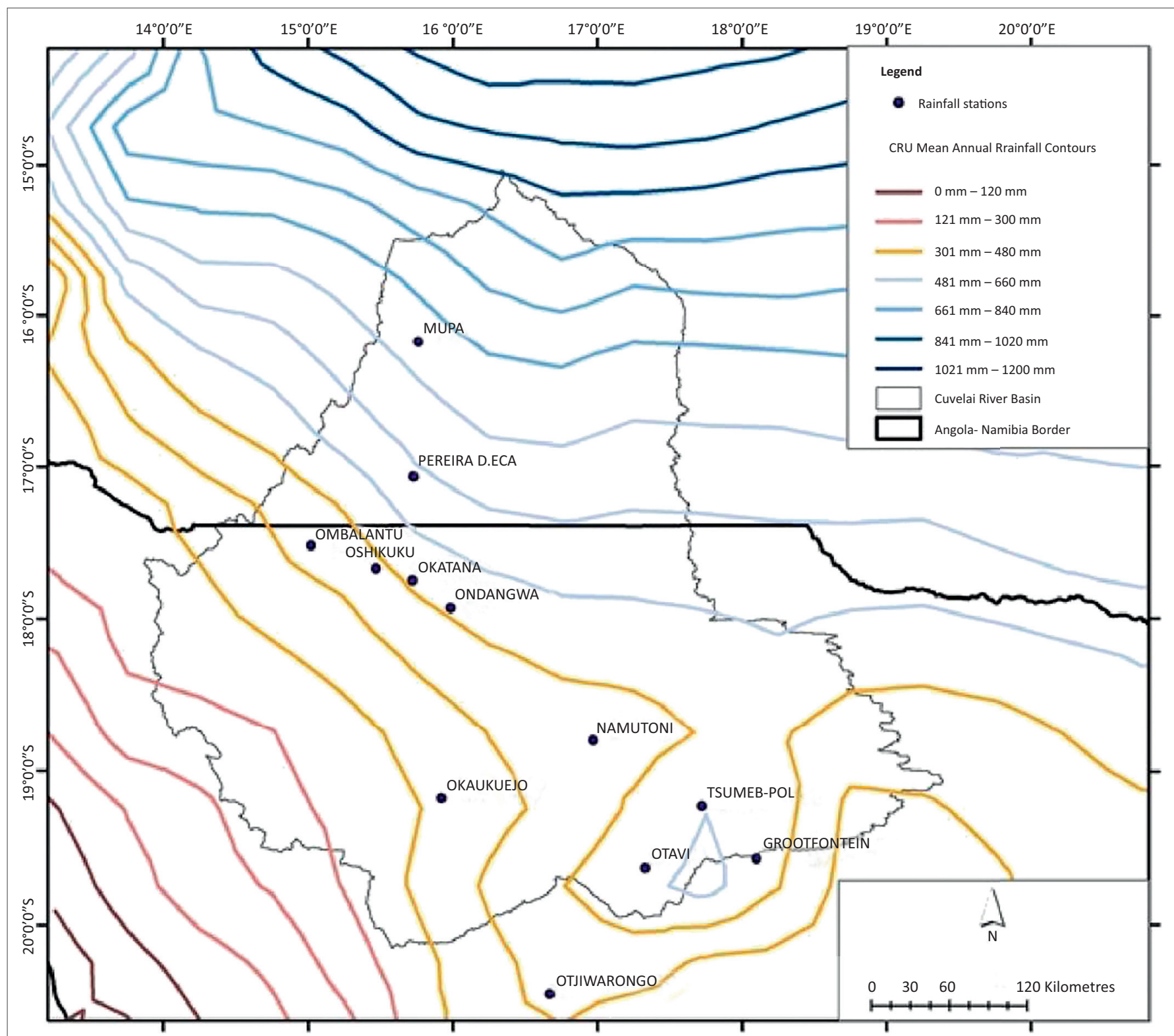

Source: Harris, I., Jones, P.D., Osborn, T.J. \& Lister, D.H., 2014, 'Updated high-resolution grids of monthly climatic observations - The CRU TS3.10 Dataset', International Journal of Climatology 34 , 623-642. http://dx.doi.org/10.1002/joc.3711

FIGURE 5: Mean annual rainfall for the CRB derived from CRU 3.21 data. The original data covered a period from $1901-2012$ at a gridded spatial resolution of $0.5^{\circ}$ and were converted into contours.

\section{Data and methods}

\section{Data}

This article has used, as reference, an existing list of flood events (Table 1) to compile an up to date archive of past flood events. It has also used the referenced events for comparison to events obtained from other sources.
The sources used in this article were:

1. flood events from the archive (Figure 4) and reproduced in Table 1

2. daily rainfall data from the Grootfontein station that will be used to calculate these indices as utilised by New et al. (2006)

3. daily rainfall data to calculate climatologies (Grootfontein)

TABLE 1: Reported flood events in the Cuvelai basin for the last 73 years from 1941 to 2013.

\begin{tabular}{|c|c|}
\hline Magnitude of flood disaster & Years \\
\hline High flows occurred in 11 years (major flood disaster events) & $1949,1953,1956,1970,1976,1977,1995,2004,2008,2009$, and 2011 \\
\hline Medium flows occurred in 18 years (medium floods) & $1943,1946,1955,1975,1979,1983,1985,1987,1991,1994,1997,1999,2000,2001,2005,2006,2010$, and 2012 \\
\hline Negligible flow occurred in 12 years (small floods) & $1941,1942,1944,1947,1950,1958,1982,1984,1990,1993,1996$, and 1998 \\
\hline No flow occurred in 18 years & 1945, 1948, 1951, 1952, 1954, 1957, 1959, 1969, 1978, 1980, 1981, 1986, 1988, 1989, 1992, 2002, 2003 and 2013 \\
\hline No data available in 13 years & $1960,1961,1962,1963,1964,1965,1966,1967,1968,1971,1972,1973$, and 1974 \\
\hline
\end{tabular}


4. information from the global disaster databases such as the EM-DAT

5. rain-gauged gridded precipitation (CRU) data

6. published literature on flood events in northern Namibia.

Table 1 summarises the known flood events for the last 73 years from 1941 to 2013. For this period the following flood events were reported:

- exceptional high flows (major floods events) - 11 times

- medium flows (medium floods) - 18 times

- negligible flow (small floods) - 12 times

- no flow - 18 times

- years with no data - 13 times.

These flood events (years) were used as references to validate results obtained from other sources that enabled the creation of an up to date archive of flood events for the study area. The archive of hydro-meteorological events (droughts and floods) will help to identify weather and climate extreme events that have caused large flood disasters in the study area. This is especially relevant as a changing and variable climate can lead to changes in the frequency, intensity, spatial extent, duration, and timing of these events (Niang et al. 2014).

Rainfall daily data from several stations in the Cuvelai basin were evaluated using two criteria. Firstly, the selection of rainfall gauge stations must have at least 30 years of data over a long-term period, including the climate (normal) standard period from 1961 to 1990 . Secondly, the stations must have limited missing data (less than 10\%) in the overall long-term record (New et al. 2006). The Grootfontein rainfall station is the only station that meets these criteria in northern Namibia. The data for the Grootfontein station were obtained from the daily Global Historical Climatology Network (GHCN-Daily) data set (Alexander et al. 2006; Gleason et al. 2002) as well as from the Namibia Meteorology Service (NMS 2015b). After selection, the data of the Grootfontein rainfall station were checked for erroneous data using data plots that enabled visual inspection. Local meteorological knowledge proved crucial in assessing a number of large precipitation outliers (compared to surrounding rainfall stations), whilst data plots were also used to detect larger temporal inhomogeneities (Klein-Tank, Zwiers \& Zhang 2009; Kruger 2006; New et al. 2006). The Grootfontein data were used to calculate the climate change extreme indices as well as annual climatologies.

The Emergency Disasters Database (EM-DAT 2015a) is the most commonly used global database and was used to obtain flood events for the CRB (Adhikari et al. 2010; Smith 2013; Tschoegl, Below \& Guha-Sapir 2006). For the period 1900 to 2014, the EM-DAT (2015c) lists only four flood disaster events for the top ten natural disasters in Namibia: 2008, 2009, 2010 and 2011 (Figure 3).

Annual precipitation climatologies and composites from the CRU product (Harris et al. 2014; Mitchell \& Jones 2005) were calculated. This monthly gridded product covers the period 1901-2012 and is composited of observations at meteorological stations across the world's land areas. The spatial resolution of the product is $0.5^{\circ}$ longitude by $0.5^{\circ}$ latitude. The dataset was used because it represents the longest temporally consistent global dataset that covers the CRB. Lastly, published literature of reported flood events in the Cuvelai basin was also compiled.

\section{Methods}

Flood events were identified from climate change extreme precipitation indices. Extreme precipitation indices are valuable for climate monitoring but are not recommended for use for activities such as weather forecasting (Klein-Tank et al. 2009). The RClimDex package (Expert Team on Climate Change Detection Monitoring and Indices [ETCCDMI 2013]) was used to perform quality control on the daily Grootfontein rainfall station data. The duration, frequency, extent, intensity and total amount of extreme long-term rainfall are crucial in identifying past and predicting future hydro-meteorological hazard events. This study used this package to calculate ten standardised indices (annually) that have proven to assess and analyse these characteristics of rainfall in order to understand and monitor a changing climate. Additionally, these indices are also designed to allow for the regional comparison of these characteristics (Klein-Tank et al. 2009). The indices are different from the traditional measures of extremes, in statistics, in that they record the occurrences of several extreme events per year whilst measures of extremes capture only the extreme value in a distribution's tail, hence they exclude some years (Alexander et al. 2006; New et al. 2006). The indices used for the present contribution can be classified into four categories:

1. precipitation frequency (R20 $\mathrm{mm}$ and $\mathrm{R} 10 \mathrm{~mm}$ )

2. precipitation intensity ( $\mathrm{XX1day,} \mathrm{RX} 5$ day, simple daily intensity index [SDII], R99p and R95p)

3. precipitation duration (consecutive dry days [CDD] and consecutive wet days [CWD])

4. precipitation amount (PRCPTOT).

Alternatively, the indices can be classified by their:

- $\quad$ percentile (R95p and R99p)

- absolute (RX1day, RX5day, R10 mm and R20 mm)

- duration (CDD and CWD) values even though the total cumulative precipitation (PRCPTOT) and SDII do not fit this classification.

Percentile-based indices (very wet days - R95p and extremely wet days - R99p) represent the amount of rainfall falling above the 95th (R95p) and 99th (R99p) percentiles. They also include, but are not limited to, the most extreme precipitation events in a year. Absolute indices represent maximum or minimum values within a year and they include the maximum 1-day precipitation amount (RX1day) and maximum 5-day precipitation amount (RX5day). Threshold indices, in contrast, are defined as the number of days on which a precipitation value falls above or below a fixed threshold and include the annual occurrence of the 
TABLE 2: The ten climate change extreme daily indices used for this study.

\begin{tabular}{|c|c|c|c|c|c|}
\hline Index & Description & Definition & Units & Grootfontein Station Trend & Regional Trend \\
\hline PRCPTOT & wet day precipitation & annual total precipitation from wet days & $\mathrm{mm}$ & Positive & Negative \\
\hline SDII & simple daily intensity index & average precipitation on wet days & $\mathrm{mm} / \mathrm{d}$ & Negative & Positive \\
\hline CDD & consecutive dry days & maximum number of consecutive dry days & days & Positive & Positive \\
\hline CWD & consecutive wet days & maximum number of consecutive wet days & days & Positive & Negative \\
\hline $\mathrm{R} 10 \mathrm{~mm}$ & heavy precipitation days & annual count of days when $R R>=10$ & days & Negative & Negative \\
\hline $\mathrm{R} 20 \mathrm{~mm}$ & very heavy precipitation days & annual count of days when $R R>=20$ & days & Positive & Negative \\
\hline R99p & extremely wet day precipitation & $\begin{array}{l}\text { annual total precipitation when } R R>99 \text { th percentile } \\
\text { of } 1961-1990 \text { daily rainfall }\end{array}$ & $\mathrm{mm}$ & Positive & Positive \\
\hline RX1day & maximum 1-day precipitation & annual maximum 1-day precipitation & $\mathrm{mm}$ & Positive & Positive \\
\hline RX5day & maximum 5-day precipitation & annual maximum consecutive 5 -day precipitation & $\mathrm{mm}$ & Negative & Positive \\
\hline
\end{tabular}

Source: Results from New, M., Hewitson, B., Stephenson, D.B., Tsiga, A., Kruger, A., Manhique, A. et al., 2006, 'Evidence of trends in daily climate extremes over southern and west Africa', Journal Source: Results from New, M., Hewitson, B., Stephenson, D.B., Tsiga, A., Kruger, A., Manhique, A.
of Geophysical Research - Atmospheres 111, D14102. http://dx.doi.org/10.1029/2005JD006289

number of heavy precipitation days greater than (>) $10 \mathrm{~mm}$ $(\mathrm{R} 10 \mathrm{~mm})$ and the number of very heavy precipitation days $>20 \mathrm{~mm}$ (R20 mm). Duration indices are defined as periods of excessive wetness or dryness and they include the indices of the CDD and the CWD. The CDD index is defined as the length of the longest dry spell in a year whilst the CWD index is the longest wet spell in a year. Other indices include annual precipitation total (PRCPTOT) and the SDII. They do not fall into any of the above categories but changes in them could have significant societal impacts (Klein-Tank et al. 2009).

Values for the ten indices were calculated from the Grootfontein daily rainfall station data. Also, linear trends for these indices for both the Grootfontein station as well as the regional rainfall stations (New et al. 2006) are listed in Table 2.

The regional trends for the abovementioned indices were obtained from New et al. (2006). Flood disaster events were identified using the global disaster databases. There are many disaster databases that catalogue flood disaster events using various criteria. These criteria resulted in underreporting of disasters in many developing countries such as Namibia, as the lack of efficient and effective disaster management communication systems - amongst others - are limiting the recording of small yet damaging events. The global databases that have information on Namibia include:

- EM-DAT (2015c)

- United Nations Office for the Coordination of Humanitarian Affairs (OCHA) - Reliefweb (2015

- International Flood Network (IFNET 2015)

- Dartmouth Flood Observatory (De Groeve 2010; Dartmouth Flood Observatory [DFO] 2015).

The DFO and EM-DAT databases have the most extensive records of flood events and their impacts, but underreporting, especially of relatively small and frequent floods, is a great obstacle to reliable validating risk estimates, in these databases and others (Adhikari et al. 2010; Smith 2013; Tschoegl et al. 2006).

Fourthly, the daily precipitation data of Grootfontein were used to derive the annual cumulative rainfall sum for each year and a least square trend line was calculated.
The regional averaged (spatial) climatologies for the region (Figure 2b, c) were derived from the CRU product using a latitude and longitude box $\left(15^{\circ} \mathrm{S}-20.1^{\circ} \mathrm{S}\right.$ and $\left.13.9^{\circ} \mathrm{E}-19.4^{\circ} \mathrm{E}\right)$ and the standardised anomalies were calculated from the data that were also aggregated to an annual dataset whilst a moving average trend line (10-year) was also calculated (Figure 8; Washington \& Preston 2006).

Published literature on reported flood events (precipitation based) were obtained and used to verify the reference flood events listed in Table 2.

These referenced flood events were compared to events derived from the extreme precipitation indices, literature, global disaster databases, the Grootfontein rainfall station's climatologies and regional averaged CRU data.

\section{Results}

The flood disaster events mentioned in the media and elsewhere prompted questions about whether such events were becoming more frequent or not. An up to date archive is needed to inform and help in the reporting of unquantified disaster events, especially in an area such as the CRB. The CRB has a chronic shortage of long-term hydro-meteorological data that are also needed for rigorous frequency analyses. This can help with the reporting of whether an event can be classified as one of the worst flood disaster events or heaviestever rainfall events in the region (Grobler 2011; Paeth et al. 2011). Thus, this section used different methods to quantify the recorded flood events (Figure 4) and compare them to data derived from different sources.

\section{Grootfontein rainfall station}

The annual precipitation of Grootfontein range from 1917 to 2014 (Figure 6) is presented. A least square linear regression line (straight) shows a declining trend for the Grootfontein annual rainfall time series whilst the 10-year moving average line emphasises the wet and dry spells experienced at the Grootfontein station. Data on flood hazard events are available for 73 years (approximately seven decades) from 1941 to 2013 (Figure 4 and Table 1; Mendelsohn et al. 2013). These seven decades will be used to derive wet and dry 
spells from the Grootfontein rainfall time series. The first decade (1940-1950) was one of the driest, using the long-term mean of $500 \mathrm{~mm}$ with only the years 1944 and 1950 recording exceptional rainfall (Rouault \& Richard 2003; Washington \& Preston 2006).

The second decade (1951-1960) started with dry conditions (1952 recorded only $267 \mathrm{~mm}$ ), although it was one of the wettest periods in the entire time series. Other studies from southern Africa also reported drought conditions for the year 1952 (Rouault \& Richard 2003; Washington \& Preston 2006). For the decade the highest recorded rainfall was $897 \mathrm{~mm}$ (1954). This value was also confirmed by the studies mentioned above. Good rainfall conditions that could result in flooding continued from the second decade into the first half of the third decade (1961-1970) with $638 \mathrm{~mm}$ recorded for the year 1963 despite the remainder of the decade experiencing dry conditions. This pattern of dry conditions is again echoed by the studies mentioned earlier. The lowest rainfall during this decade was $147 \mathrm{~mm}$ (1970) and this low rainfall for this year was also highlighted by the earlier studies.

Dry conditions continued into the fourth decade (1971-1980) whilst wetter conditions occurred at the end of the decade. The highest annual accumulative rainfall of $950 \mathrm{~mm}$ (1978) was recorded whilst $886 \mathrm{~mm}$ (1974) was measured earlier. Rouault and Richard (2003) have reported floods for the years: 1972, 1974, 1975, 1976 and 1978 whilst Washington and Preston (2006) had also reported these years as wet periods.

The fifth decade (1981-1990) started with wet conditions and ended with dry conditions. The highest rainfall was $662 \mathrm{~mm}$ (1982) whilst the lowest within this decade was $319 \mathrm{~mm}$ (1984). Floods (1981, 1988 and 1989) and droughts $(1982,1983,1984$ and 1987) were reported by Rouault and Richard (2003) whilst Washington and Preston (2006) reported dry conditions between 1979 and 1987. According to DWA (2015) and Nilsson (2012), the Orange-Vaal basin at Upington (discharge station) recorded two of the highest monthly peak flows within the station's 72 year record.

The sixth decade (1991-2000) was relatively dry compared to the second and the fourth decades whilst the last decade (2001-2013) was the driest for the Grootfontein rainfall station. In the sixth decade, $729 \mathrm{~mm}$ (1994) was recorded whereas the lowest recorded annual accumulative rainfall figures of $68 \mathrm{~mm}$ (2004) and $75 \mathrm{~mm}$ (2007) were recorded in the last decade which was one of the driest decades (DWA 2015).

To summarise, using an annual accumulative total of $900 \mathrm{~mm}$ for the Grootfontein rainfall station, the wettest spells (highest seven totals), in decreasing order, can also be identified as: 1978 (950 mm), 1923 (915 mm), 1934 (898 mm), 1954 (897 mm), 1974 (885 mm), 1944 (881 mm) and 1950 (873 mm). Table 3 shows the descriptive statistics for the Grootfontein rainfall station (96-year time series).

\section{Extreme precipitation indices}

Extreme precipitation indices were used to identity and validate flood events in this study. Identifying extreme precipitation events are important as these events are often associated with flood hazards and, ultimately, higher risk of the vector and epidemic diseases such as malaria and cholera (Anyamba et al. 2006). Floods can also be highly beneficial in drylands (especially in Africa) as the floodwaters infiltrate and recharge alluvial aquifers along ephemeral river pathways, extend water availability to dry seasons and drought years and also sustain rain-fed agriculture (Morin et al. 2009).

Regionally, studies have shown that the most extreme daily precipitation indices, over southern Africa, showed approximately identical proportions of increasing as well as decreasing trends for the subregion, even though a very small number of station trends are statistically significant for any index (New et al. 2006).

The southern African region has many diverse climatic zones which can therefore produce extensive trends in inter-annual and decadal-scale variability of rainfall, hence, secular trends would not be easily detected. New et al. (2006), reported that only three indices have statistically significant

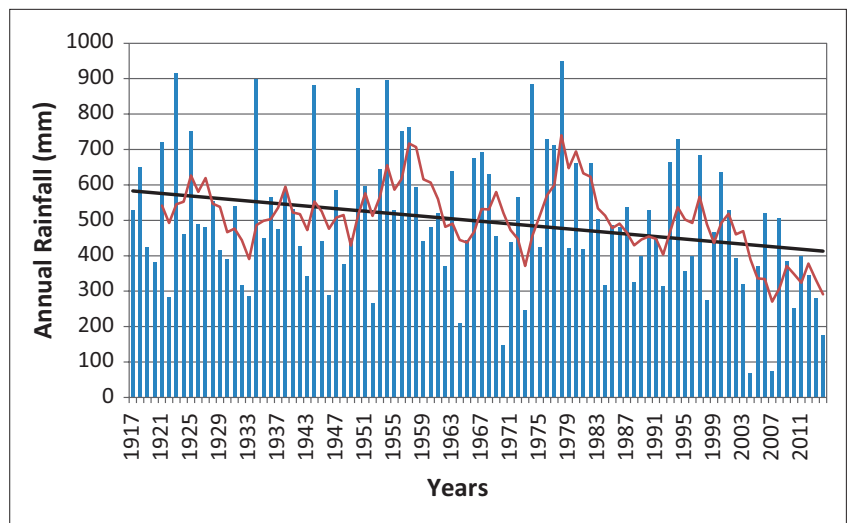

Source: Data from Namibia Meteorological Service (NMS), 2015b, Namibia meteorological service, viewed 16 June 2015, from http://www.meteona.com/

FIGURE 6: The annual rainfall of Grootfontein from 1917 to 2014 with a least square linear regression and 10-year moving average trend lines.

TABLE 3: Descriptive statistics for the Grootfontein rainfall station derived from a 96-year time series: 1917-2014.

\begin{tabular}{ll}
\hline Statistical parameters & Values \\
\hline Mean & 498.1375 \\
Standard Error & 19.22688 \\
Median & 478.5 \\
Mode & 425 \\
Standard Deviation & 188.3842 \\
Sample Variance & 35488.61 \\
Kurtosis & -0.00836 \\
Skewness & 0.325199 \\
Range & 882 \\
Minimum & 68.2 \\
Maximum & 950.2 \\
Sum & 47821.2 \\
Count & 96 \\
\hline
\end{tabular}


increasing trends in southern Africa: annual maximum 1-day precipitation (RX1day), average wet day precipitation (SDII) and maximum dry spell duration (CDD). They further reported that another three indices, the maximum 5-day precipitation (RX5day) and the total precipitation indices on extreme rainfall days (R95p and R99p) also show (nonsignificant) increasing regional trends. They also reported that there were decreasing trends (non-significant) for four indices: annual precipitation (PRCPTOT), heavy precipitation days (R10 $\mathrm{mm}$ and $\mathrm{R} 20 \mathrm{~mm}$ ) and CWD. They reported increases as well as decreases for the subregion, the former for average rainfall intensity and the amount of rainfall on extreme rainfall days and periods whilst the latter for the total rainfall as well as number of days with heavy rainfall (see Table 2 for the regional trends; New et al. 2006).

An increase of the CDD index over southern Africa was reported by New et al. (2006) and it is the only index that shows a consistent trend. As the indices used in this study are calculated on an annual basis, the CDD recorded dry spells (days) within a year and, therefore, highlighted the length of the dry season but could not effectively record the number of dry days that occurred in a particular rainy season.

Large parts of the region experience one long rainy season from October to April (Yuan et al. 2014) and the result from this index confirms the findings of other studies, notably, a shortening of the rainy season (Tadross, Hewitson \& Usman 2005). The rural population of the region practice subsistence farming and a variability in seasonal characteristics such as the onset and cessation of rain, and dry spell frequency can be damaging to agriculture, and a short rainy season can be more disastrous. The last mentioned study, amongst others (Tadross, Hewitson \& Usman 2003), investigated the inter-annual variability of the onset of the maize growing season on Zimbabwe and South Africa and found that the onset was starting later in the period between 1979 and 2001. These findings can enhance farmers' understanding of the onset of the season and enable them to predict the planting of maize (a vital cereal in the region) as it requires consistent water during its germination phase and, thus, planting maize at the right time is vital resulting from many resourceconstraints.

Table 2 summarises the trends for all ten extreme precipitation indices for the Grootfontein rainfall station and the regional (southern Africa) trend as positive (increasing) or negative (decreasing) trend, whilst Figure 7 shows the graphs of the ten indices calculated from daily rainfall data of the Grootfontein station. Because of the rigorous selection criteria of the Grootfontein station compared to other surrounding regional rainfall stations, data for years between 1968 and 1989 were not plotted, and all graphs have gaps for these years with the exception of the year 1975 (Figure 7).

The increases for the extreme indices calculated for the Grootfontein station compared favourably to those reported by New et al. (2006). These were: RX1day and CDD, whilst non-significant increase was only for the R99p. Regionally, no significant decreases were found but a decrease was reported for the Grootfontein station (R10 mm index, Table 2).

\section{Regional Climate Research Unit data}

The inter-annual and decadal-scale variability of precipitation over the study area (spatially-averaged box around the Cuvelai basin) for CRU data are depicted in Figure 8. The 10-year moving average trendline illustrates the decadalscale variability of precipitation whilst the anomalies are portrayed by bars using standard deviations. The first decade (1940-1950) was very variable with six negative anomalies and five positive anomalies. The highest negative anomaly occurred in 1941 (-1.7) whilst the highest positive anomaly was in 1950 (2.8). The trend line for the second decade (19511960) shows positive anomalies representing above normal rainfall conditions, although this decade had four positive standard anomalous years and five negative anomalous years. The highest positive anomaly was in 1951 (1.35) whilst the lowest negative anomaly was in the following year, 1952 (-0.93). The trend line for the third decade (19611970) shows that it was a below average decade with dry conditions, which are reflected with the four positive and the five negative anomalies with the highest positive being in 1967 (1.83) and lowest negative in 1970 (-0.67). These 2 years correspond with wet periods (floods) in South Africa and dry conditions (droughts) respectively (DWA 2015; Nilsson 2012; Rouault \& Richard 2003; Washington \& Preston 2006). As in the second decade, the trend line for the fourth decade (1971-1980) shows above normal rainfall conditions reaching a peak in 1974, flood hazard conditions characterised this year, as confirmed by the aforementioned studies. The fourth decade also had six positive and four negative anomalous years with the highest positive anomaly being in 1974 (1.6) whilst the lowest negative anomaly was in $1980(-0.81)$. Studies (mentioned earlier) in South Africa reported flood events for most of these six positive anomalies: 1974, 1975, 1976, 1977 and 1978. The next two decades (1981-1990 and 1991-2001) experienced exceptionally dry conditions peaking in 1987 $(-1.06)$ and in $1992(-1.43)$, respectively, for these two decades. These 2 years had major drought conditions in South Africa as well as in the region (DWA 2015; Nilsson 2012; Rouault \& Richard 2003; Washington \& Preston 2006). In these two decades, the only two positive anomalous years were 1993 (0.28) and 1997 (0.62). The dry conditions prevailed during the first part of the seventh decade (2001-2010), according to the trend line (Figure 8 ) and five positive as well as five negative anomalous years are shown in Figure 8 with the highest positive anomalous year being 2009 (2.88) and the lowest negative anomaly year falling in $2007(-0.80)$.

\section{Discussion}

Table 4 summarises the different sources (hydrometeorological data, global disaster data bases, extreme precipitation indices, and published disaster events in literature) used in this article to identify flood events for the last seven decades for which data for flood events (as referenced) are available. The referenced flood events that were used by this article were shown in Figure 4 and Table 1. 


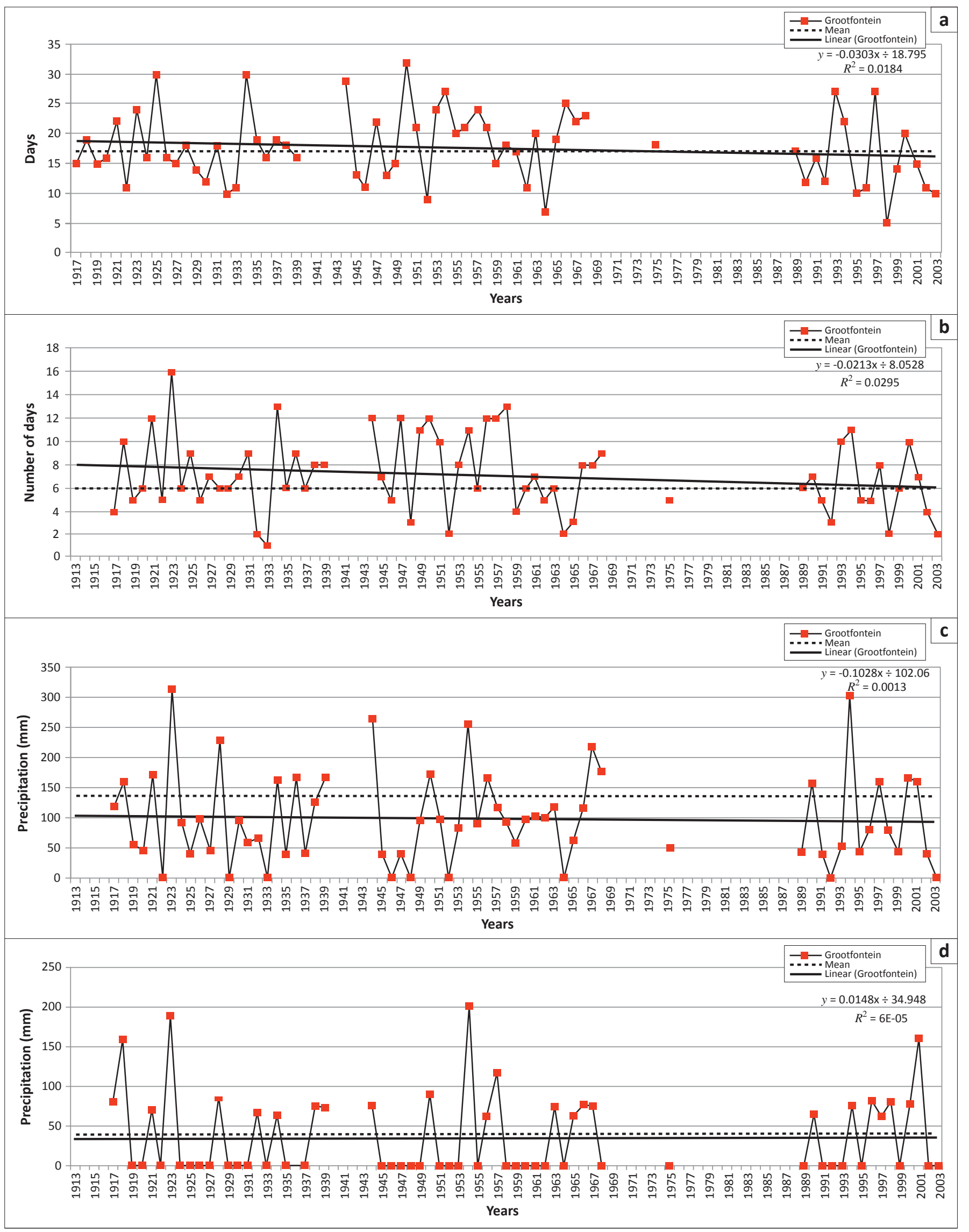

Source: Data provided by Namibia Meteorological Service (NMS), 2015b, Namibia meteorological service, viewed 16 June 2015, from http://www.meteona.com/

FIGURE 7: Ten climate change extreme precipitation indices for the Grootfontein rainfall station: (a) annual count of days when RR $>10 \mathrm{~mm}$; (b) annual count of days when $R R>=20 \mathrm{~mm}$; (c) annual total precipitation when RR > 95 th percentile of 1961-1990 daily rainfall; (d) annual total precipitation when RR > 99th percentile of 1961-1990 daily rainfall; (e) annual maximum 1-day precipitation; ( $\mathrm{f}$ ) annual maximum consecutive 5-day precipitation; ( $\mathrm{g}$ ) maximum number of consecutive wet days; ( $\mathrm{h}$ ) maximum number of consecutive dry days; (i) annual total precipitation from wet days and (j) average precipitation on wet days. Figure 7 continues on next page $\rightarrow$ 


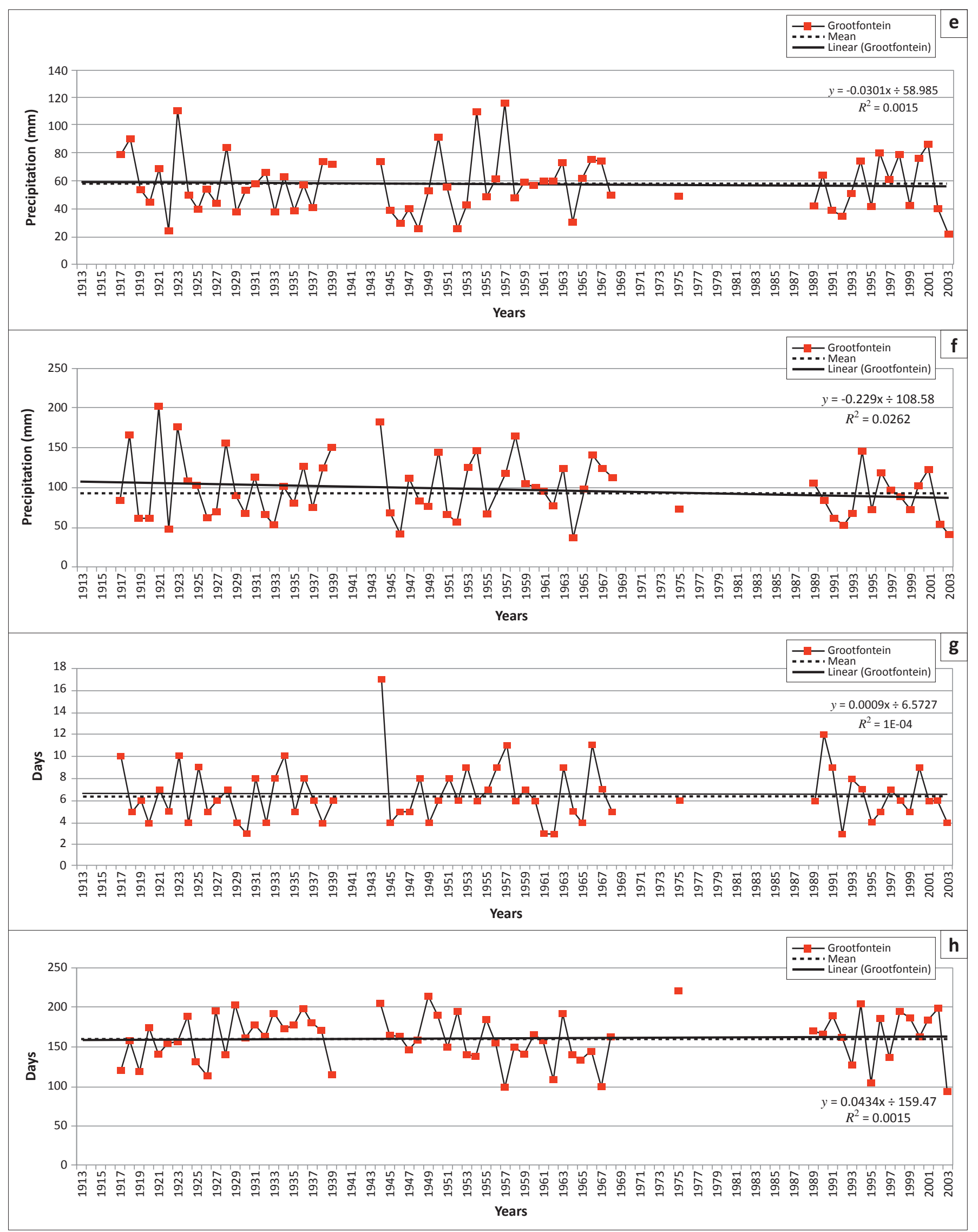

Source: Data provided by Namibia Meteorological Service (NMS), 2015b, Namibia meteorological service, viewed 16 June 2015, from http://www.meteona.com/

FIGURE 7 (Continues...): Ten climate change extreme precipitation indices for the Grootfontein rainfall station: (a) annual count of days when RR $>10$ mm; (b) annual count of days when $R R>=20 \mathrm{~mm}$; (c) annual total precipitation when $R R>95^{\text {th }}$ percentile of 1961-1990 daily rainfall; (d) annual total precipitation when RR > 99th percentile of 1961-1990 daily rainfall; (e) annual maximum 1-day precipitation; (f) annual maximum consecutive 5-day precipitation; (g) maximum number of consecutive wet days; (h) maximum number of consecutive dry days; (i) annual total precipitation from wet days and (j) average precipitation on wet days. 


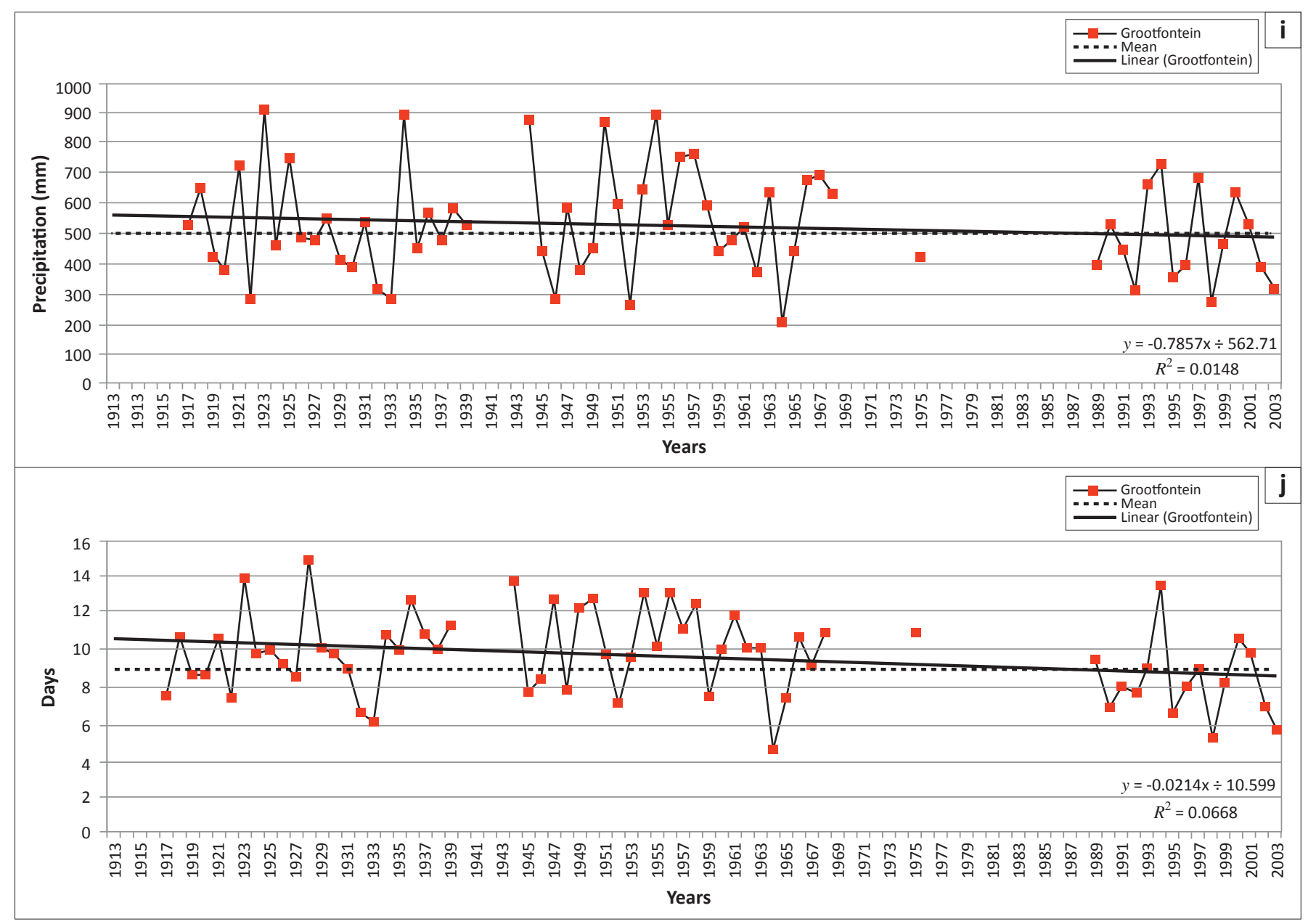

Source: Data provided by Namibia Meteorological Service (NMS), 2015b, Namibia meteorological service, viewed 16 June 2015, from http://www.meteona.com/

FIGURE 7 (Continues...): Ten climate change extreme precipitation indices for the Grootfontein rainfall station: (a) annual count of days when RR > 10 mm; (b) annual count of days when $R R>=20 \mathrm{~mm}$; (c) annual total precipitation when $R R>95^{\text {th }}$ percentile of 1961-1990 daily rainfall; (d) annual total precipitation when $R R>99$ th percentile of 1961-1990 daily rainfall; (e) annual maximum 1-day precipitation; (f) annual maximum consecutive 5-day precipitation; (g) maximum number of consecutive wet days; (h) maximum number of consecutive dry days; (i) annual total precipitation from wet days and (j) average precipitation on wet days.

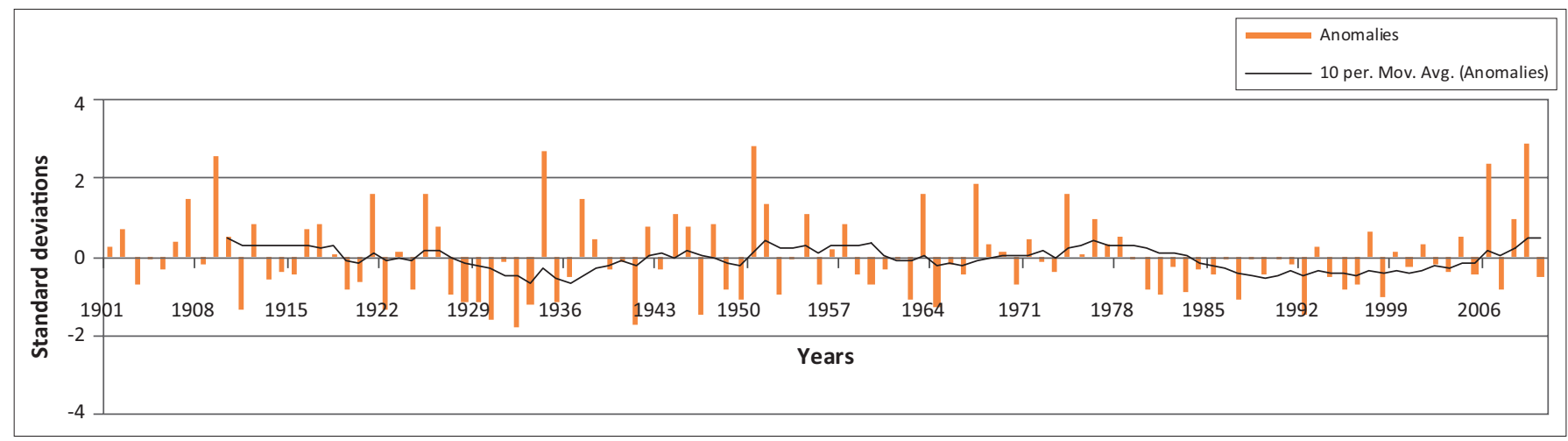

Source: Harris, I., Jones, P.D., Osborn, T.J. \& Lister, D.H., 2014, 'Updated high-resolution grids of monthly climatic observations - The CRU TS3.10 Dataset', International Journal of Climatology 34 , 623-642. http://dx.doi.org/10.1002/joc.3711

FIGURE 8: Standardised anomalies of the spatial (regional) averaged CRU data with a 10-year moving average trend line.

For the first decade (1940-1950) eight flood disaster events were reported and three of these events were reported by BAR Namibia (2012), Engert (1997), climatologies derived from CRU, Grootfontein station rainfall data as well as from a few extreme precipitation indices. All the major sources, listed in Table 4, reported the years 1944, 1947 and 1950 as the most likely years for extreme precipitation and hence flooding. Figure 8 shows that this decade had experienced a dry spell except for the year 1944 when the long-term (96 years) mean of $500 \mathrm{~mm}$ was used. Figure 8 also shows the standardised anomalies derived from spatially and timeaveraged CRU (monthly) data and confirmed that this decade 


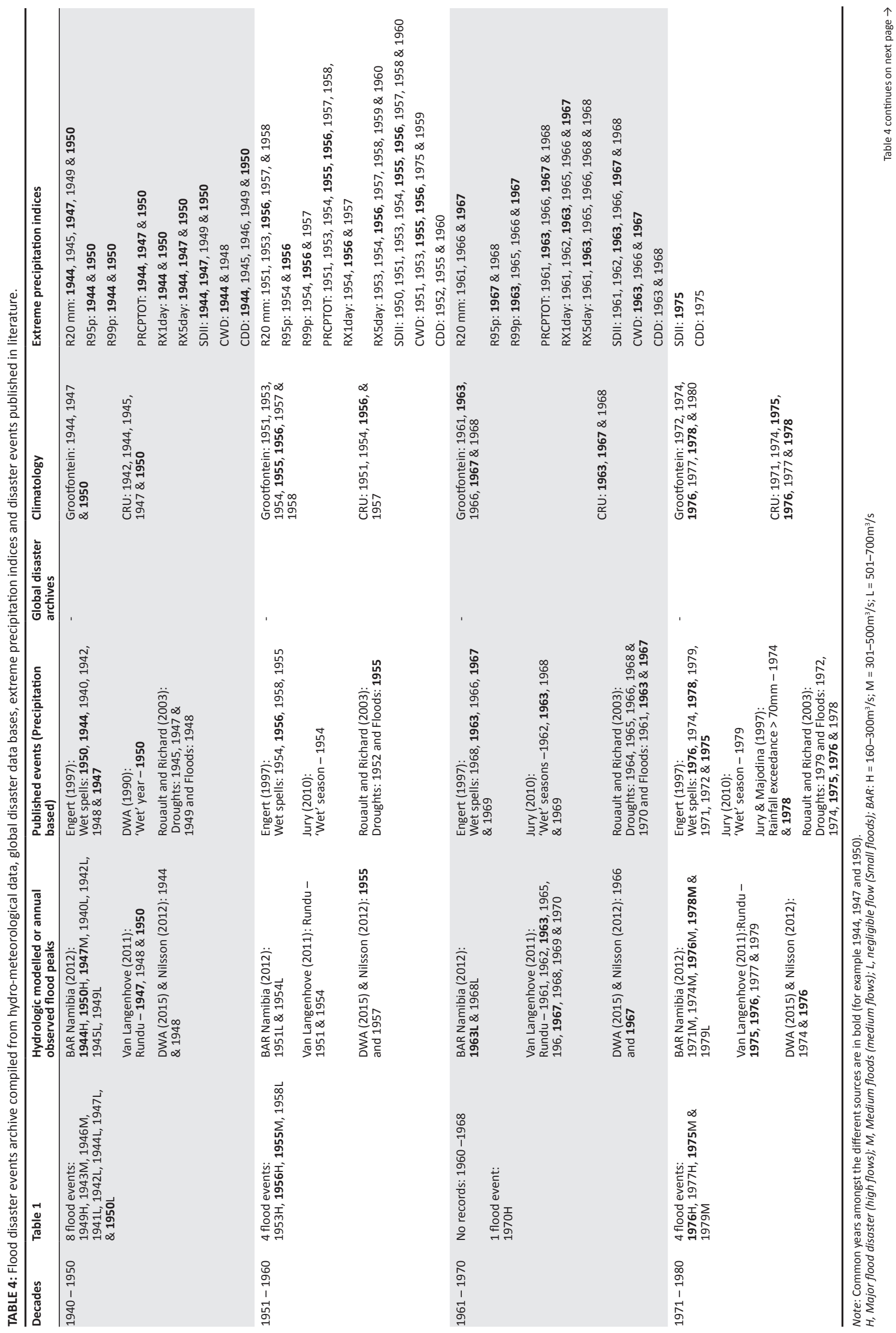







had minimal rainfall. This decade was also preceded with a very dry period between 1927 and 1942. Other studies such as Washington and Preston (2006) confirmed wet years for 1944 and 1948 whilst the Orange-Vaal basin at the Upington discharge gauge also recorded high peak flows for these 2 years (DWA 2015; Nilsson 2012).

The second decade (1951-1960) had only four referenced events and only one flood disaster event (1956), which was commonly occurring amongst the different sources used to identify them. Figures 7 and 8 confirm, using 10-year moving averages, that this decade was one of the wettest periods for Grootfontein and the region. This period had the most possible flood disaster events, as illustrated by the extreme precipitation indices. Other studies such as Washington and Preston (2006) confirmed these possible wet periods: 1953, 1954, 1954, 1955, 1956 and 1957, whilst the Orange-Vaal basin at the Upington discharge gauge also recorded high peak flows for 2 of these years: 1955 and 1957 (DWA 2015; Nilsson 2012).

The third decade (1961-1970) lacks sufficient observational data for the period 1960-1968 (Table 4) but one flood event (1970) was reported during that period as a referenced flood event (Table 1). However, 1963 was the most common year in which a flood was reported by the different sources consulted (Figure 8). The first half of the decade is recorded as very dry whilst the second half had reasonable wet spells. Overall, Figure 8 (10-year moving average) indicates a dry decade regionally whilst 1967 was a very wet year. Other studies such as Washington and Preston (2006) confirmed these possible dry periods: 1961, 1962, 1964, 1965, 1966, 1968 and 1970 as well as wet periods: 1963, 1967 and 1969 whilst the Orange-Vaal basin at the Upington discharge gauge recorded high peak flows for 2 years: 1966 and 1967 (DWA 2015; Nilsson 2012).

The fourth decade (1971-1980) had the fewest recorded flood events from all sources, only one index (SDII) reported an extreme event for 1975. Generally, 1975 was reported by most of the sources as a year during which flood events had occurred. This decade also began with dry spells and ends with wet spells that included extreme precipitation for 1974 and 1978 for the Grootfontein station. Regionally, it was a wet year with only 1973 appearing to be a dry year. The extreme precipitation indices failed to record this, as these years were not plotted, resulting from the rigorous rainfall selection criteria. Other studies such as Washington and Preston (2006) reported three dry periods: 1973, 1979 and 1980 as well as wet periods: 1971, 1972, 1974, 1975, 1976, 1977, 1978 and 1979, whilst the Orange-Vaal basin at the Upington discharge gauge recorded high peak flows for 2 years: 1974 and 1976 (DWA 2015; Nilsson 2012).

The fifth decade (1981-1990) started as a wet year (Figures 7 and 8) but ended with dry conditions. Table 4 shows that 1984 was the most commonly reported year for flood events even though the extreme precipitation events failed to report it, resulting from reasons given earlier for the period 19681989. This decade started with wet conditions and ended with the worst drought (1991-1992) reported in southern Africa (Benson \& Clay 1998). Figure 7 illustrates the period of the drought conditions from 1983-2004 with good rainfall only in the years 1993, 1997, 1999, 2001 and 2004. Other studies such as Washington and Preston (2006) reported a dry period from 1981 until 1987 and wet periods only for: 1988 and 1989, whilst the Orange-Vaal basin at the Upington discharge gauge recorded its highest peak flow: 1988 (DWA 2015; Nilsson 2012).

The sixth decade covers the period 1991-2000 and includes the driest periods in southern Africa. The CDD index reported 7 years as very dry periods whilst the year 2000 is widely reported (Table 4) as a year for a flood event. Figure 7 confirms the five good rainfall years for the Grootfontein station, even though Washington and Preston (2006) only reported three wet periods: 1991, 1997 and 1998, whilst the rest of the decade was dry. The Orange-Vaal basin in South Africa also experienced severe drought conditions, hence the Upington discharge gauge did not record any high flow peaks for this decade (DWA 2015; Nilsson 2012).

For the last decade (2001-2013) the highest number of reported flood events was nine (Table 4). The years 2008, 2009, 2010 and 2011 were widely reported (Figure 3 and Table 4) as years when flood disaster events occurred. Regionally, this period started with dry conditions and recorded the most consecutive flood disaster events in Namibia, causing severe damage. These consecutive flood events occurred during the latter part of this decade. In general, the annual precipitation for the Grootfontein station shows a significant decreasing trend (Figure 6), whilst Figure 7 confirmed the same dry years whilst these wet spells (consecutive flood events) are also highlighted. The Upington discharge gauge recorded a high flow peak for 2011 (DWA 2015; Nilsson 2012).

One of the main objectives of this study is to identify drought and flood events during periods where no observational hydro-meteorological data are available (Figure $4 \&$ Table 1 ). The most incomplete observational records are reported for the third decade (1961-1970), of 13 years (Table 1). These 13 years are within the climate normal period (1961-1990) used by climatologists to compare climatological trends to that of the past, or what is considered 'normal', hence when the same years within this period are absent, indices will not be calculated, as in this article (1968-1989). Using the methods followed in this article, hydro-meteorological events were assigned to 10 of the 13 years. A few years $(1965,1966 \& 1968)$ yielded contradicting results (events), for example, these 3 years were reported as droughts in South Africa, whilst several sources reported them as flood hazard years in Namibia. This article assumed that the dominant rain-producing systems in the region have a large enough spatial extent to be well represented in the different data sources used for the subregion (Tadross et al. 2003, 2005). Future work should, therefore, investigate these and other differences (hydro-meteorological 
events) that might have resulted from local topography or other uncertainties. Additionally, this article did not calculate the magnitude of these hazardous events, hence rigorous frequency analysis should be performed on both available modelled and observed flow and stage data as well on satellite-based rainfall estimates and land-based rainfall gauge data. This would be a challenging task in an ungauged and under gauged basin such as the Cuvelai.

Lastly, as a result of increasing changes in the climate, landuse and extreme precipitation, disaster risk reduction and flood risk management strategies are essential in adapting to the envisaged increasing flood risk. This necessitates an accurate inventory of hydro-meteorological events, which can also be updated to provide a quantified spatial and temporal distribution of floods, including magnitude, frequency, and duration. The major limitation of this article is that it does not include methods that can help with the identification of historical records of catastrophic floods, such as records of physical signs of water levels on old buildings, memories of old citizens, historical documents, news reports and archive reports from meteorological and hydrological national services as well as detail discharge and rainfall frequency analysis resulting from data scarcity.

\section{Conclusion}

The present contribution produced an up to date archive of flood events (years) by validating and supplementing referenced flood events, and also comparing them against indices of extreme precipitation (years) derived from daily climate data as well as data derived from other sources for northern Namibia.

Generally, for the extreme precipitation indices, no significant regional trends were identified, which does not come as a surprise for a continent where different factors affect regional rainfall, and where there are few consistent and statistically significant trends in extreme precipitation indices. Also, for the statistical regional trends, similar to other studies: an increase in average dry spell length was found for other indices such as the average rainfall intensity and annual 1-day maximum rainfall indices, whilst decreasing trends were found for the Grootfontein station. Furthermore, for the Grootfontein station, there is an indication of decreasing trends, for both total annual precipitation as well as for the total number of wet days annual precipitation.

The study appended the hydro-meteorological records, for the developed archive, for the 'no records' period of 19601968 by adding the years 1963 and 1967 and possibly 1968 as flood prone years. It also identified years when floods would have not been possible and, hence, these years require in-depth hydrologic and hydraulic modelling to confirm the occurrences of flood hazard events.

These findings highlighted the lack of and difficulty with obtaining observed hydro-meteorological data and performing analyses on them in Africa, where a large rural population entirely relies on precipitation for its water supply. This also, ultimately, determines strategies of food production and also the mobility of migrant groups.

The results from this article will provide an improved understanding of past extreme precipitation events that are required for scientists, practitioners, policymakers and civil society to better compare and refer to past and present flood and drought hazard events.

This article updated the inventory of past flood events by using different sources such as: hydro-meteorological data, global disaster databases, climate change extreme precipitation indices and disaster events published in literature.

\section{Acknowledgements Competing interests}

The authors declare that they have no financial or personal relationships which may have inappropriately influenced them in writing this article.

\section{Authors' contributions}

F.C.P. (University of Canterbury) did the analysis, wrote and compiled the article as part of a chapter for his PhD thesis in the Geography Department at the University of Canterbury, Christchurch, New Zealand. C.G. (University of Canterbury) and P.Z-R. (University of Canterbury) provided guidance and also edited earlier versions of the article. They also helped with the conceptual framework of the article.

\section{References}

Abbas, F., Ahmad, A., Safeeq, M., Ali, S., Saleem, F., Hammad, H.M. \& Farhad, W. 2014, 'Changes in precipitation extremes over arid to semiarid and subhumid Punjab, Pakistan', Theoretical and Applied Climatology 116, 671-680. http:// dx.doi.org/10.1007/s00704-013-0988-8

Adhikari, P., Hong, Y., Douglas, K.R., Kirschbaum, D.B., Gourley, J., Adler, R. \& Brakenridge, G.R., 2010, 'A digitized global flood inventory (1998-2008): Compilation and preliminary results', Natural Hazards 55, 405-422. http://dx.doi. org/10.1007/s11069-010-9537-2

Alexander, L.V. \& Arblaster, J.M., 2009, 'Assessing trends in observed and modelled climate extremes over Australia in relation to future projections', International Journal of Climatology 29, 417-435. http://dx.doi.org/10.1002/joc.1730

Alexander, L.V., Zhang, X., Peterson, T.C., Caesar, J., Gleason, B., Klein Tank, A.M.G., et al. , 2006, 'Global observed changes in daily climate extremes of temperature and precipitation', Journal of Geophysical Research - Atmospheres 111, D05109. http://dx.doi.org/10.1029/2005JD006290

Anyamba, A., Chretien, J-P., Small, J., Tucker, C.J. \& Linthicum, K.J. 2006, 'Developing global climate anomalies suggest potential disease risks for 2006-2007', International Journal of Health Geographics 5, 60. PMID: 17194307, http://dx.doi org/10.1186/1476-072X-5-60

Barnolas, M. \& Llasat, M.C., 2007, 'A flood geodatabase and its climatological applications: The case of Catalonia for the last century', Natural Hazards and Earth System Science 7, 271-281. http://dx.doi.org/10.5194/nhess-7-271-2007

Benson, C. \& Clay, E., 1998, The impact of drought on Sub-Saharan African economies, The International Bank for Reconstruction and Development/The World Bank, Washington, D.C.

Buro of Architecture (BAR) Namibia, 2012, Design and supervision of the construction of the dike around Oshakati: Report on the hydrological and hydraulic model, Ministry of Regional and Government, Housing and Rural Development, Oshakat Town Council, Windhoek.

Conway, D., Persechino, A., Ardoin-Bardin, S., Hamandawana, H., Dieulin, C. \& Mahé, G. 2009, 'Rainfall and water resources variability in Sub-Saharan Africa during the Twentieth Century', Journal of Hydrometeorology 10(1), 41-59. http://dx.doi org/10.1175/2008JHM1004.1

Dartmouth Flood Observatory (DFO), 2015, Global active archive of large flood events, viewed 16 June 2015, from http://www.dartmouth.edu/ floods/Archives/ index.html 
De Groeve, T., 2010, 'Flood monitoring and mapping using passive microwave remote sensing in Namibia', Geomatics, Natural Hazards and Risk 1, 19-35. http://dx.doi. org/10.1080/19475701003648085

Department of Water Affairs (DWA), 1990, Regional water master plan for the Owambo region, Department of Water Affairs, Windhoek.

Department of Water Affairs (DWA), 2015, Hydrological services - flood peaks uptington discharge station, Department of Water Affairs, Pretoria, viewed 16 June 2015, from https://www.dwaf.gov.za/hydrology/

Di Baldassarre, G., Montanari, A., Lins, H., Koutsoyiannis, D., Brandimarte, L. \& Bloschl, G., 2010, 'Flood fatalities in Africa: From diagnosis to mitigation', Geophysical Research Letters 37, L22402. http://dx.doi.org/10.1029/2010GL045467

Emergency Disasters Database (EM-DAT), 2015a, The OFDA/CRED Internationa Disaster Database, Université catholique de Louvain, Brussels, viewed 22 October 2015, from http://www.emdat.be

Emergency Disasters Database (EM-DAT), 2015b, Fatalities from meteorological disasters from 1948 to 2015 in Africa, The OFDA/CRED International Disaster Database, Université catholique de Louvain, Brussels, viewed 22 October 2015, from http://www.emdat.be/advanced_search/index.html

Emergency Disasters Database (EM-DAT), 2015c, Top 10 natural disasters in Namibia for the period 1900 to 2014, The OFDA/CRED International Disaster Database,
Université catholique de Louvain, Brussels, viewed 22 October 2015, from http:// Université catholique de Louvain, Brussels,

Engert, S., 1997, 'Spatial variability and temporal periodicity of rainfall in the Etosha National Park and surrounding areas in northern Namibia', Madoqua 20(1), 115-120.

Expert Team on Climate Change Detection Monitoring and Indices (ETCCDMI), 2013 , RClimDex software, viewed 16 June 2015, from http://etccdi.pacificclimate.org/ software.shtml

Filali-Meknassi, Y., Ouarda, T.B.M.J. \& Wilcox, C., 2014, Knowledge platform - Phase I: Data access, availability and quality assessment for the development of a flood forecasting model for Namibia, UNESCO, Windhoek.

Frich, P., Alexander, L.V., Della-Marta, P., Gleason, B., Haylock, M., Klein Tank, A.M.G. \& Peterson, T., 2002, 'Observed coherent changes in climatic extremes durin the second half of the twentieth century', Climate Research 19, 193-212. http:// dx.doi.org/10.3354/cr019193

Gleason, B., Groisman, P., Peterson, T.C., Vose, R. \& Ezell, R., 2002, 'A new global daily temperature and precipitation dataset', paper presented at the 13th Symposium on Global Change and Climate Variations, American Meteorological Society, 12-17 January, Orlando, Florida.

Grobler, J., 2011, 'Namibia in flood after heaviest rain in 120 years', Mail \& Guardian, 08 April, viewed 07 October 2015, from http://mg.co.za/article/2011-04-08 namibia-in-flood-after-heaviest-rain-120-years

Harris, I., Jones, P.D., Osborn, T.J. \& Lister, D.H., 2014, 'Updated high-resolution grids of monthly climatic observations - The CRU TS3.10 Dataset', International Journa of Climatology 34, 623-642. http://dx.doi.org/10.1002/joc.3711

Helmschrot, J., Muche, G., Hillmann, T., Kanyanga, J., Butale, M., Nascimento, D. et al., 2015, 'SASSCAL WeatherNet to support regional weather monitoring and climaterelated research in Southern Africa', paper presented at the Proceedings of the 11th Kovacs Colloquium: Hydrological Sciences and Water Security: Past, Present and Future, IAHS Publications, Paris, June 16-17, 2014, p. 366

Hipondoka, M.H.T., 2005, 'The development and evolution of Etosha Pan, Namibia', Unpublished PhD, Institut fuer Geographie and Geologie, Bayerischen JuliusMaximilians-University of Würzburg.

Hirabayashi, Y., Kanae, S., Emori, S., Oki, T. \& Kimoto, M., 2008, 'Global projections of changing risks of floods and droughts in a changing climate', Hydrological Sciences Journal 53, 754-772. http://dx.doi.org/10.1623/hysj.53.4.754

Hoerling, M., Hurrell, J., Eischeid, J. \& Phillips, A., 2006, 'Detection and attribution of twentieth-century northern and southern African rainfall change', Journal of Climate 19, 3989-4008. http://dx.doi.org/10.1175/JCLI3842.1

Hofer, T. \& Messerli, B., 2006, Floods in Bangladesh: History, dynamics and rethinking the role of the Himalayas, United Nations University Press, Tokyo.

International Flood Network (IFNET), 2015, Worst Floods, viewed 07 October 2015 from http://www.internationalfloodnetwork.org/index.htm

James, R. \& Washington, R., 2013, 'Changes in African temperature and precipitation associated with degrees of global warming', Climatic Change 117, 859-872. $\mathrm{http}: / / \mathrm{dx}$.doi.org/10.1007/s10584-012-0581-7

Jonkman, S.N., 2005, 'Global perspectives on loss of human life caused by floods', Natural Hazards 34, 151-175. http://dx.doi.org/10.1007/s11069-004-8891-3

Jonkman, S.N., Vrijling, J.K. \& Vrouwenvelder, A.C.W.M., 2008, 'Methods for the estimation of loss of life due to floods: A literature review and a proposal for a new method', Natural Hazards 46, 353-389. http://dx.doi.org/10.1007/s11069nes-9227-5

Jury, M., 2010, 'Climate and weather factors modulating river flows in southern Angola', International Journal of Climatology 30, 901-908. http://dx.doi. org/10.1002/joc.1936

Jury, M.R. \& Engert, S., 1999, 'Teleconnections modulating inter-annual climate variability over northern Namibia', International Journal of Climatology 19 1459-1475. http://dx.doi.org/10.1002/(SICI)1097-0088(19991115)19:13<1459:: AID-JOC397>3.0.CO;2-AS

Jury, M.R. \& Majodina, M., 1997, 'Preliminary climatology of southern Africa extreme weather: 1973-1992', Theoretical and Applied Climatology 56, 103-112. http:// dx.doi.org/10.1007/BF0086378

Kangombe, F.N., 2010, 'The vegetation of Omusati and Oshana Regions, centralnorthern Namibia', Department of Plant Science, Faculty of Natural and Agricultura Science, Magister Scientiae, University of Pretoria, Pretoria, pp. 1-166.
Klein-Tank, A.M.G., Zwiers, F.W. \& Zhang, X., 2009, Guidelines on analysis of extremes in a changing climate in support of informed decisions for adaptation, World Meteorological Organization, Washington.

Kruger, A.C., 2006, 'Observed trends in daily precipitation indices in South Africa: 1910-2004', International Journal of Climatology 26, 2275-2285. http://dx.doi. org/10.1002/joc.1368

Kundzewicz, Z.W., Kanae, S., Seneviratne, S.I., Handmer, J., Nicholls, N., Peduzzi, P. et al., 2014, 'Flood risk and climate change: Global and regional perspectives', Hydrological Sciences Journal 59, 1-28. http://dx.doi.org/10.1080/02626667.20 13.857411

Mason, S.J., Waylen, P.R., Mimmack, G.M., Rajaratnam, B. \& Harrison, J.M., 1999 'Changes in extreme rainfall events in South Africa', Climatic Change 41, 249-257. http://dx.doi.org/10.1023/A:1005450924499

Mendelsohn, J., el-Obeid, S. \& Roberts, C., 2000, A profile of north-central Namibia, Environmental Profiles Project, Windhoek.

Mendelsohn, J., Jarvis, A., Roberts, C. \& Robertson, T., 2009, Atlas of Namibia; a portrait of the land and its people, Jonathan Ball Publishers, Cape Town.

Mendelsohn, J., Jarvis, A. \& Robertson, T., 2013, A profile and atlas of the Cuvelai Etosha Basin, RAISON \& Gondwana for the Sustainable Integrated Water Resources Management Project, Ministry of Agriculture, Water and Forestry, Windhoek.

Mendelsohn, J. \& Weber, B., 2011, The Cuvelai Basin: Its water and its people, Development Workshop, Luanda \& RAISON, Windhoek.

Miller, R.M., Pickford, M. \& Senut, B., 2010, 'The Geology, Palaeontology and evolution of the Etosha Pan, Namibia: Implications for terminal Kalahari deposition', South African Journal of Geology 113, 307-334. http://dx.doi.org/10.2113/gssajg.113.3.307

Mitchell, T.D. \& Jones, P.D., 2005, 'An improved method of constructing a database of monthly climate observations and associated high-resolution grids', Internationa Journal of Climatology 25, 693-712. http://dx.doi.org/10.1002/joc.1181

Moise, A.F. \& Hudson, D.A., 2008, 'Probabilistic predictions of climate change for Australia and southern Africa using the reliability ensemble average of IPCC CMIP3 model simulations', Journal of Geophysical Research-Atmospheres 113(D15),126. http://dx.doi.org/10.1029/2007JD009250

Morin, E., Grodek, T., Dahan, O., Benito, G., Kulls, C., Jacoby, Y., Langenhove, G.V. et al. 2009, 'Flood routing and alluvial aquifer recharge along the ephemeral arid Kuiseb River, Namibia', Journal of Hydrology 368, 262-275. http://dx.doi.org/10.1016/j. jhydrol.2009.02.015

Mufeti, P. \& Katjizeu, M., 2013, 'New Flooding Patterns on the borders of Namibia', paper presented at the TIGER Workshop 2013: Achievements \& Future Planning, Namibia Hydrological Services, Hotel Ramada Plaza Tunis, Tunisia, October 21-22.

Namibia Hydrological Services (NHS), 2015, Flood report archives, Ministry of Agriculture, Water and Forestry, Windhoek, viewed 16 June 2015, from http:// matsu-namibiaflood.opensciencedatacloud.org/bulletins

Namibia Meteorological Service (NMS), 2015a, Climate \& data bank: Rainfall progression charts at Ondangwa from 2005/2006 to 2013/2014, Windhoek, viewed 16 June 2015, from http://www.meteona.com/index.php/climate/ rainprogress/ondangwa

Namibia Meteorological Service (NMS), 2015b, Namibia meteorological service, viewed 16 June 2015, from http://www.meteona.com/

New, M., Hewitson, B., Stephenson, D.B., Tsiga, A., Kruger, A., Manhique, A. et al., 2006, 'Evidence of trends in daily climate extremes over southern and wes Africa', Journal of Geophysical Research - Atmospheres 111, D14102. http:// dx.doi.org/10.1029/2005JD006289

Niang, I., Ruppel, O.C., Abdrabo, M.A., Essel, A., Lennard, C., Padgham, J. et al., 2014 'Africa - IPCC WGII AR5', Chapter 22, in V.R. Barros, C.B. Field, D.J. Dokken, M.D. Mastrandrea, K.J. Mach, T.E. Bilir et al. (eds.), Climate change 2014: Impacts, adaptation, and vulnerability. Part B: Regional aspects. Contribution of working group II to the fifth assessment report of the intergovernmental panel on climate change, pp. 1199-1265, Cambridge University Press, Cambridge and New York, NY.

Nilsson, E., 2012, Flood impact assessment and proposals for improved flood management in Keimoes, South Africa, Lund University, Lund, Sweden.

Ohl, C.A. \& Tapsell, S., 2000, 'Flooding and human health: The dangers posed are not always obvious', BMJ 321, 1167-1168.

Orlowsky, B. \& Seneviratne, S.I., 2012, 'Global changes in extreme events: Regional and seasonal dimension', Climatic Change 110, 669-696. http://dx.doi.org/10.1007/ s10584-011-0122-9

Paeth, H., Fink, A.H., Pohle, S., Keis, F., Mächel, H. \& Samimi, C., 2011, 'Meteorological characteristics and potential causes of the 2007 flood in sub-Saharan Africa', International Journal of Climatology 31, 1908-1926. http://dx.doi.org/10.1002/ joc.2199

Reliefweb, Disasters in Namibia, United Nations Office for the Coordination of Humanitarian Affairs (OCHA), viewed 07 October 2015, from http://reliefweb.int/ disasters?country=166\#content

Rouault, M. \& Richard, Y., 2003, 'Intensity and spatial extension of drought in South Africa at different time scales', Water SA 29, 489-500. http://dx.doi.org/10.4314/ wsa.v29i4.5057

Seneviratne, S.I., Nicholls, N., Easterling, D., Goodess, C.M., Kanae, S., Kossin, J. et al., 2012, 'Changes in climate extremes and their impacts on the natural physical environment', in C.B. Field, V. Barros, T.F. Stocker, D. Qin, D.J. Dokken, K.L. Ebi et al., (eds.), Managing the risks of extreme events and disasters to advance climate change adaptation (SREX): Special report of the intergovernmental pane on climate change (IPCC), pp. 109-230, Cambridge University Press, Cambridge and New York, NY.

Seth, A., Rauscher, S.A., Rojas, M., Giannini, A. \& Camargo, S.J., 2011, 'Enhanced spring convective barrier for monsoons in a warmer world?', Climatic Change 104, 403-414. http://dx.doi.org/10.1007/s10584-010-9973-8 
Shongwe, M.E., Van Oldenborgh, G.J., Van Den Hurk, B.J.J.M., De Boer, B., Coelho, C.A.S. \& Van Aalst, M.K., 2009, 'Projected changes in mean and extreme precipitation in Africa under global warming. Part I: Southern Africa', Journal of precipitation in Africa under global warming. Part I: Southern Africa',
Climate 22, 3819-3837. http://dx.doi.org/10.1175/2009JCLI2317.1

Simonović, S.P., 2012, Floods in a changing climate - Risk Management, Cambridge University Press, Cambridge.

Smith, K., 2013, Environmental hazards: Assessing risk and reducing disaster, Taylor and Francis, Hoboken.

Stengel, H.W., 1963, 'The Cuvelai - A contribution to the hydrography of South West Africa/Namibia', Water Affairs in SWA, Afrika-verlag der Kreis, Windhoek.

Tadross, M., Hewitson, B.C. \& Usman, M., 2003, 'Calculating the onset of the maize growing season over southern Africa using GTS and CMAP data', CLIVAR Exchanges $8($ No. $2 / 3), 27,48-50$

Tadross, M.A., Hewitson, B.C. \& Usman, M.T., 2005, 'The interannual variability on the onset of the maize growing season over South Africa and Zimbabwe', Journal of Climate 18, 3356-3372. http://dx.doi.org/10.1175/JCLI3423.1

Teegavarapu, R.S.V., 2012, Floods in a changing climate: Extreme precipitation, University Press, Cambridge.

Tschoegl, L., Below, R. \& Guha-Sapir, D., 2006, 'An analytical review of selected data sets on natural disasters and impacts', paper presented at the UNDP/CRED workshop on improving compilation of reliable data on disaster occurrence and impact, EM-DAT, Bangkok, April 2-4.
Unganai, L.S. \& Mason, S.J., 2001, 'Spatial characterization of Zimbabwe summer rainfall during the period 1920-1996: Research letter', South African Journal of Science 97, 425-431.

Van Der Waal, B.C.W., 1991, 'Fish life of the Oshana Delta in Owambo, Namibia, and the translocation of Cunene species', Madoqua 17, 201-209.

Van Langenhove, G., 2008, Hydrological perspective on 2008 floods in Northern Namibia, with special reference to Cuvelai area, Department of Water Affairs, Windhoek.

Van Langenhove, G., 2011, 'Flood early warning systems in Namibia: Using weather, climate and hydro info for contingency planning', SADC DRR - Hands on DRR Training, Windhoek, viewed 08 September 2015, from http://www.iwrm-namibia. info.na

Washington, R. \& Preston, A., 2006, 'Extreme wet years over southern Africa: Role of Indian Ocean sea surface temperatures', Journal of Geophysical Research Atmospheres 111, D15104. http://dx.doi.org/10.1029/2005JD006724

Wuensch, S.X. \& Curtis, S., 2010, 'Can satellites be used to detect extreme precipitation events?: An example from the Carolinas', Southeastern Geographer 50, 244-257. http://dx.doi.org/10.1353/sgo.0.0084

Yuan, C., Tozuka, T., Landman, W. \& Yamagata, T., 2014, 'Dynamical seasonal prediction of Southern African summer precipitation', Climate Dynamics 42, 3357-3374. http://dx.doi.org/10.1007/s00382-013-1923-5 